\title{
SPÓJNOŚĆ SPOŁECZNA, GOSPODARCZA I TERYTORIALNA A ROZWÓJ ENERGETYKI W STRATEGII NA RZECZ ODPOWIEDZIALNEGO ROZWOJU
}

\begin{abstract}
Streszczenie
Celem artykułu jest ocena wskazanych w Strategii na rzecz Odponiedzialnego Rozpoju do roku 2020 (zperspektywa do 2030 roku) zapisów dotyczących spójności oraz ocena wizji rozwoju energetyki pod kątem jej wpływu na wzmacnianie spójności. Podstawowe znaczenie w Strategii ma spójność społeczna. Polityka regionalna ma zapewniać osiaganie spójności terytorialnej i zrównoważenie rozwoju kraju. Selektywne podejście do polityki regionalnej, uwzględniające ujęcie sektorowe, mogłoby służyć rozwojowi z wykorzystaniem lokalnych zasobów. Jednak w Strategii założono prymat technologii węglowych w wytwarzaniu energii, scentralizowany model wytwarzania energii elektrycznej oraz preferencje dla stabilnych źródeł odnawialnych. Będzie to godzić w osiaganie celów w zakresie spójności: społecznej, ekonomicznej i terytorialnej. Spowoduje duży wzrost kosztów wytwarzania, a w ślad za tym, cen energii dla odbiorców. Za właściwy można uznać kierunek działań określanych jako energetyka rozproszona. Będą temu także sprzyjać istniejące i zapowiadane zasady finansowania inwestycji ze źródeł unijnych.
\end{abstract}

Słowa kluczowe: Polska, rozwój, energetyka, spójność

\section{SOCIAL, ECONOMIC, AND TERRITORIAL COHESION AND GROWTH OF ENERGY SECTOR IN STRATEGY FOR RESPONSIBLE DEVELOPMENT}

Summary

The aim of this paper is to assess the provisions concerning cohesion included in the 2020 Strategy for Responsible Development (with a view to 2030) and to assess the vision of the development of energy in terms of its impact on strengthening cohesion. Social cohesion is a key notion in the document. Regional policy is to ensure territorial cohesion and sustainable development of the country. A selective approach to regional policy, taking into account a sectoral approach, could foster development based on local resources. However, the Strategy assumes the priority of carbon technology in the generation of energy, a centralized model of electricity generation, and preference for sustainable renewable sources. This will make it difficult to achieve the goals of social, economic, and territorial cohesion, which can result in a significant increase in manufacturing costs and thus higher energy prices for consumers. What should be regarded as a strength of the Strategy is the proposed development of distributed generation of energy. It will also be supported by the existing and announced rules for financing EU investments.

Key words: Poland, development, energy sector, cohesion

JEL Classification: Q43, Q 48, Q 56, R 58 


\section{Wstęp}

Umacnianie spójności: gospodarczej, społecznej i terytorialnej jest jednym z głównych celów Unii Europejskiej. W art. 174 Traktatu o funk.jonowaniu Unii Europejskiej stwierdza

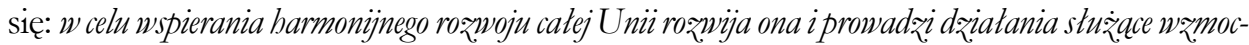
nieniu jej spójności gospodarčej, spotecznej i terytorialnej. W sžrzólności Unia zmierza do zmniejszenia dysproporgi w poziomach rozinoju różnych regionón oraz zacofania regionów najmniej uprayzwilejowanych [Wersje skonsolidowane Traktatu o Unii Europejskiej..., 2012].

Traktat nakłada na państwa członkowskie zobowiązania w zakresie tworzenia warunków do osiagania celów spójności. W szczególności określa, że: prowadz̨ swoje polityki gospodarcze $i$ koordynuja je w taki sposób, aby osiagnać takize cele okerélone w artykule 174. Pryy formu-

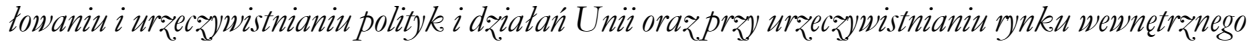
bierze sie pod unvage cele okereslone w artykule 174 i prayycrynia sie do ich realizacji [Wersje skonsolidowane Traktatu o Unii Europejskiej..., 2012].

Wizję rozwoju Polski określa Strategia na rzecz. Odpowiedzৃialnego Rozwoju do roku 2020 (zperspektywa do 2030 roku) [2017] (dalej Strategia). Jednym z istotnych elementów kształtujących rozwój i wpływających na spójność: gospodarczą, społeczną i terytorialna jest zapewnienie energii. Celem niniejszego artykułu jest ocena wskazanych w Strategii zapisów dotyczących spójności oraz ocena wizji rozwoju energetyki pod kątem jej wpływu na wzmacnianie spójności. W artykule wykorzystano metodę badania dokumentów.

\section{Problem spójności w definiowaniu celów Strategii}

W Strategii wyznaczono cel główny projektowanych działań rozwojowych. Jest nim:

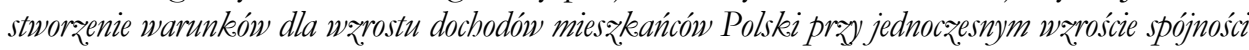
w nymiarze: spotecznym, ekonomicznym, środowiskonym i terytorialnym [Strategia..., 2017, s. 7]. Działania mają koncentrować się na trzech celach szczegółowych, w tym rozwoju społecznie wrażliwym i terytorialnie zrównoważonym. Wyznaczono tzw. obszary horyzontalne oddziałujące na osiagnięcie celów Strategii, w których będa podejmowane interwencje. Są to: „Kapitał ludzki i społeczny”, „Cyfryzacja”, „,Transport”, „Energia”, „Środowisko”, „Bezpieczeństwo narodowe”.

W podstawowych założeniach, odnoszących się do rozwoju Polski, element spójności gospodarczej nie został wyeksponowany, mimo stwierdzenia, że: Strategia jest ukierunkowana na inklusymmy rozwoój spotecżno-gospodarczy [Strategia..., 2017, s. 49]. W strategii przyjęto, że: gtówna sita napedowa rožwoju i priorytetem publicznym jest spójność spoteczna. Strategia podporzadkownje driatania w sferze gospodarczej osiaganin celów zwiqzanych z poziomem i jakościa syycia obywateli Polski. (...) Prayjecie takiego wrorca bedzie sprayjać unolnieniu kapitalu ludzkeiego, w₹mocnieniu kapitatu społecznego i tym samym optymalnemu wykoryystywaniu potencjatu rozwojowego catego kraju [Strategia..., 2017, s. 49].

W Strategii zamieszczono wyjaśnienie sposobu podejścia do problemu spójności w ramach celu szczegółowego - „Rozwój społecznie wrażliwy i terytorialnie zrównoważony”. W stosunku do spójności społecznej stwierdzono: Utraymujace sie zróżnicowania spo- 


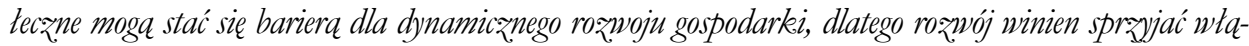
rzeniu spotecznemu, co oznacza gospodarke o uysokim poziomie zatrudnienia, dobrej jak ości i przedsiebiorczości. Oznacza to z jednej strony koniecznosíc adaptacji gospodarki do aystepujacych trendón demograficznych, $w$ szczególności poprzez zapewnienie dostepności ustug swiadczonych $w$ odpowiedzi na

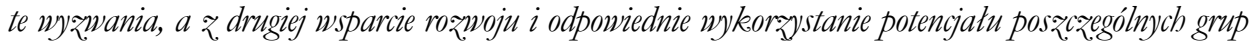
społecznych na rynku pracy [Strategia..., 2017, s. 53].

Natomiast przez zrównoważony terytorialnie rozumie się w Strategii: rozwoój wszystkich terytoriow przez wzmacnianie ich potencjatów endogenicznych i çynników rozwoju oraz likwidacje barier $i$ wtaczenie w procesy rozwojowe regionón zmagajacych sie z trudnościami o charakterze restrukturyzacyjnym $i$ adaptacyjnym (makroregion Polski W schodniej, Ślask), obszarów wiejskich wraz zich lokalnymi ośrodkami miejskimi oraz srednich miast tracacych funkeje spoleczno-gospodarcze. Oznacza to m.in. prowadzenie skutecznej polityki regionalnej dostosowanej do specyfiki danego terytorium i obejmujacej działania sturqace aktywizacji gospodarczej, rozuojowi lokahnych rynków pracy i mobilizacii zawodowej mieszkeańcón, çy poprawie dostepu do ustug publicznych z uykoraystaniem potencjatón lokalmych i subregionalnych gospodarek, jak również własnych zasobów [Strategia..., 2017, s. 53].

Podejście do definiowania problemu spójności ma także znaczenie w kontekście celów przyszłej polityki regionalnej. W Strategii zostały określone trzy cele polityki regionalnej, ti.:

- zrównoważony rozwój kraju wykorzystujacy indywidualne potencjały poszczególnych terytoriów;

- wzmacnianie regionalnych przewag konkurencyjnych;

- podniesienie skuteczności i jakości wdrażania polityk ukierunkowanych terytorialnie.

Zapisano również, iż: polityka regionalna bedzie dażyta do zapewnienia bardziej zrównowazonego rozwoju kraju poprzez zintegrowane interwencje nykkorzystujace miejscowe zasoby i potencjaly poszczególnych terytorión $i$ dostarczanie odpowiednich zasobów dla zainicjowania trwatego wzrostu i miejsc pracy w obszarach o mniej korzystnych uwarunkowaniach rozwojowych. (...) Wyzwaniem dla wsyystkich polskich regionón jest optymalne wykeorysstanie wtasnego potengjatu rozwojowego w celu zwiekszenia konkurencyjności gospodarki i jednoczésnie zapewnienia warunków dla trwatego $i$ zrównoważonego rozizoju. Nowa polityka regionalna bedzie selektywna i, w wiekssym niž dotychczas zakeresie, koncentrowata instrumenty wsparcia na tworzenie warunków do warostu konkurencyjności, innowacyjności i inwestycji w wybranych sektorach, majacych podstawowe znaczenie dla gospodarek regionalnych [Strategia..., 2017, s. 182].

Zestawienie dwóch podejść do problemu spójności terytorialnej - unijnego i krajowego - potwierdza spostrzeżenia sformułowane przez M. Gospodarowicza - kategoria spójności terytorialnej jest ujmowana w różny sposób w dokumentach strategicznych Unii Europejskiej (tj. na poziomie europejskim), a inaczej na poziomie krajowym. Z perspektywy europejskiej koncepcja spójności terytorialnej dotyczy raczej wyrównywania poziomu rozwoju pomiędzy poszczególnymi krajami/regionami, tj. zbliżenia bądź konwergencji, która wiąże się ze wsparciem finansowym z Unii Europejskiej pod kątem spójności (z wykorzystaniem funduszy spójności). Dzięki temu, kraje Unii Europejskiej korzystają z tych funduszy, w szczególności regiony o najniższym poziomie rozwoju. Natomiast w ujęciu krajowym spójność określa się jako niedopuszczenie do nadmiernych zróżnicowań pomiędzy regionami i w ramach regionów [Gospodarowicz, 2016]. 
W Strategii spójności gospodarczej nie poświęcono odrębnego miejsca. Jest ona raczej podporządkowana działaniom związanym z osiaganiem spójności społecznej i terytorialnej. Aspekty gospodarcze spójności społecznej zwykle dotycza: warunków życia mieszkańców, zjawisk zachodzących na rynku pracy oraz technicznych możliwości prowadzenia działalności gospodarczej. Natomiast w ramach spójności terytorialnej działania powinny uwzględniać relatywne znaczenie gospodarcze regionu dla funkcjonowania terytorium jako całości. Osiaganie spójności jest jednym z czynników decydujących o sukcesie gospodarczym. Jednak efekty ekonomiczne w ostateczności stanowią o możliwości prowadzenia polityki spójności jako całości. Sa także podstawą do prowadzenia odpowiedniej - uwzględniającej spójność społecznąi terytorialna - polityki regionalnej.

Selektywne podejście do polityki regionalnej, które opiera się na ujęciu sektorowym, będzie sprzyjać rozwojowi z wykorzystaniem lokalnych zasobów. Jednocześnie nadanie prymatu spójności społecznej będzie kierować działania w stronę tych produktów i usług, które mają szczególne znaczenie dla wyrównywania szans i równoważenia konsumpcji. Jedną z dziedzin, które bardzo dobrze wpisują się w te obszary, jest zrównoważona energetyka. Szczególnie rozwój zdecentralizowanej energetyki pozwala na spożytkowanie potencjałów lokalnych oraz subregionalnych zasobów przyrodniczych i pracy, wpływa na lokalne bezpieczeństwo energetyczne, zachęca do rozwoju przedsiębiorczości i współpracy między producentami, prosumentami i odbiorcami energii, umożliwia dostęp do tanich źródeł zaopatrzenia w energię i usług związanych z jej dostarczaniem. Zrównoważona energetyka może więc być sposobem na osiaganie celów Strategii w zakresie spójności. Jest to również zgodne z założeniami europejskiej strategii dotyczącej zrównoważonej energetyki [Europejska strategia..., 2006].

\section{Cele rozwoju energetyki a spójność w obszarach horyzontalnych Strategii}

Koncepcje rozwoju energetyki w Strategii głównie są związane z dwoma obszarami horyzontalnymi, takimi jak „Energia” i „Środowisko”. Niewielką wzmiankę można także znaleźć w obszarze „Technologia”. Obejmuje ona zastosowania technologii Smart Grid, która przyniesie poprawę przepływu energii między wytwórcami a odbiorcami energii [Strategia..., 2017, s. 292].

Istotną rolę w zapewnianiu spójności społecznej powinno odegrać kształtowanie bezpieczeństwa energetycznego. Wymaga ono dywersyfikacji źródeł, surowców oraz sposobu wytwarzania i dystrybucji energii, choć rozwiazania Strategii nie zmierzają w kierunku modelu zrównoważonej energetyki, a w konsekwencji będą ograniczać możliwości zapewniania spójności.

Kluczowe wydaje się stwierdzenie: koniecżna jest odbudowa potencjału uytwórczego źródet wytwarzania opartego o dostepne w kraju surowce w stopniu umo:̀liwiajacym zaspokojenie popytu [Strategia..., 2017, s. 321]. Przesłanką rozwiązań w obszarze energii elektrycznej ma być rozwój: zrónnoważonych z popytem źródet energii w oparciu o krajowy potencjat i tylko cześsciowo wspomaganego potaczeniami transgranicznymi [Strategia..., 2017, s. 321]. W Strategii sformułowano następująca konkluzję: Do najważniejszych myzwań stojacych przed calym sektorem

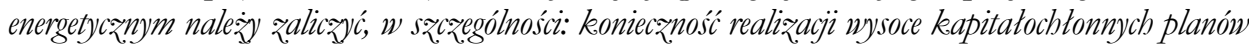


inwestycyjyych zwiazanych z budowa nowych wielkoskalowych mocy wytwórcaych oraz modernizacja już istniejacego majatku sieciowego i nytwórczego. Warto podkreślic, ze kierunek inwestycyjny bęrie miat istotny wptyw na prayszłta strukture produkcii energii w nasaym kraju, a ta z kolei bedrie oddzialywać na powiazane zenergetykeq sektory [Strategia..., 2017, s. 323].

Jednakże będzie to oznaczać utrzymanie scentralizowanego systemu wytwarzania energii elektrycznej i w efekcie wzrost kosztów jej dostarczania w regiony północne i wschodnie kraju, czyli tam, gdzie energia elektryczna jest już dla odbiorców najdroższa. Ograniczenie transgranicznych dostaw energii elektrycznej zmniejszy możliwości importu taniej energii. W znacznym stopniu uniemożliwi korzystanie z zalet technologii Smart Grid.

W Strategii zwrócono uwagę na to, że: særeroki rozwój cieptownictwa oparty na gazie ziemnym rodzi uzależnienie od zagranicznych dostaw. (...) We wprowadzaniu dywersyfikacji pomocne może być substytucyjne traktowanie nowych źródet energii i wykorsystanie innowacyjnych rozwiqazan. W obszarach stabiej zurbanizowanych ciepto, gaz, jak i elektrycznosí moga pochodzić z biogazowni. Odpowiedni dobór odnawialnych $i$ innych źródet wytwarzania energii w ramach klastrów energï, spótdzielni energetycznych itp. moze lokalnie zapewnić samonystarczalnośc i tym samym bezpieczeństwo energetyczne [Strategia..., 2017, s. 321].

W świetle powyższych stwierdzeń można mieć wattpliwości w sprawie postulatu Strategii, który brzmi: polska polityka bespieczenistwa powrinna byó na poziomie krajowym spójna koncepcyjnie, wykeonalna techničnie i w zasiegu potencjalu platniczego polskich nabywców energii [Strategia..., 2017]. W szczególności wytwarzanie energii elektrycznej, bazujące na kosztownych technologiach węglowych, jak również preferowanie wytwarzania ciepła dzięki jednym z najdroższych technologii biomasowych spowoduje duży wzrost kosztów wytwarzania, a w ślad za tym, cen energii dla odbiorców. Ponadto, koszty i ceny energii będa rosły ze względu na rosnące koszty środowiskowe. Tym samym obciążenie przedsiębiorstw i gospodarstw domowych kosztami energii będzie większe. W kontekście przyjętych założeń Strategii wzrost ten będzie mocniej obciążać użytkowników energii już obecnie ponoszących relatywnie wysokie koszty. Dotyczyć to będzie zwłaszcza odbiorców na terenach północnych i wschodnich Polski oraz na terenach wiejskich.

Autorzy Strategii dostrzegają konieczność pogodzenia: nystarczajaco silnego zaplecza konwencjonalnych, wielkoskalowych sit wytwórcsych w zawodowej energetyce ze źródtami rozproszonymi funkejonujacymi jako uzupetnienie dla średniej wielkości aglomeracij oraz klastrami, spółdzielniami energetycznymi itp. o znacznym poziomie autonomii. Jednak uważaja, że: dotowanie OZE, jeśli nie bedrie moglo zostá uyygaszone, poninno z jednej strony preferować rozwiazania zapenmiajace maksymahna dyspo-

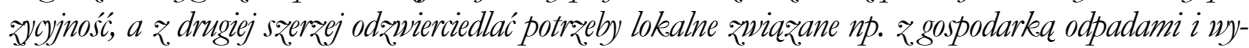
korzystaniem miejscowego potencjatu. Koniecznym jest zatem zapewnienie mo:̀liwości bilansowania i wspótdžiatania żródeł OZE z innymi ŕródtami, niepodlegajacymi ograniczeniom ze strony sit natury, bardziej efektywnymi, stabilnymi i latwiej sterowalnymi [Strategia..., 2017, s. 323]. Jest to wskazanie na technologie o wysokich kosztach wytwarzania. Jeśli nie zapewni się wsparcia ze źródeł publicznych, to zainteresowanie prywatnego kapitału tym sektorem będzie znikome. Świadczą o tym wyniki pierwszej aukcji na dostawy energii ze źródeł odnawialnych [Graczyk, Wielewska, Silarska, 2017]. 
Pozytywnym przejawem w kwestii zapewniania spójności jest w Strategii, następująca konstatacja: wraz ₹.postepem technologii rapewniajacym wrrost uydajności i spadek cen dla matych instalacii OZE dedykowanych grupie indywidualnych konsumentów bedzie rosta rola wykorsystywanych na wlasne potrzeby zasobów wytwarzania. (...) Ten segment rynku zacznie sie dynamicznie rozwijać, jeśli rozwiazany zostanie problem taniego i efektywnego magasynowania energii. Do tego czasu rozwój segmentu prosumenckiego może być wspomagany przez oferte wirtualnego magazynowania poprzez oddawanie wytworzonych nadwyżek do sieci elektroenergetycznej w celu odebrania jej w okeresie, gdy jest potrzebna [Strategia..., 2017, s. 323]. Takie podejście oznacza jednak brak wsparcia dla inicjatyw, w których prosument miałby możliwość sprzedaży nadwyżek energii do sieci. Natomiast to rozwiązanie byłoby korzystne zwłaszcza dla obszarów wiejskich wymagających pomocy w ramach polityki spójności i o niewielkim stopniu nasycenia infrastrukturą przemysłowa. Na tych terenach trudno będzie o tworzenie klastrów czy spółdzielni energetycznych, które zgodnie z zapisami Strategii, mają być preferowane.

W obszarze działań horyzontalnych „Środowisko” w Strategii najwięcej uwagi poświęcono ograniczeniu zjawiska niskiej emisji na obszarach zurbanizowanych. Przewiduje się: rožój efektywnego energetycznie niskoemisyjnego cieptownictwa systemowego i matych kottowni lokalmych, stosowanie kogeneracji w wytwarzaniu ciepta, standaryzacje kottów grzewcrych na paliwa state oraz paliw stalych wylkoryystywanych wo ogrzewaniu indywidualnym $i$ kottowniach lokalnych [Strategia..., 2017, s. 346]. Te działania dobrze wpisują się w koncepcję zrównoważonego rozwoju energetyki, lecz mają być ukierunkowane na tereny o przekroczonych standardach jakości powietrza. Nie są więc propozycją dla wszystkich obszarów i w związku z tym ich oddziaływanie na osiaganie spójności nie będzie znaczące. W szczególności nie pojawi się ono tam, gdzie nie ma problemu niskiej emisji ze względu na małą aktywność gospodarczą i niewielką gęstość zabudowy.

W kwestii osiagania spójności za pozytywny można uznać projekt działań interwencyjnych, określanych jako energetyka rozproszona. Ma on na celu rozwój wytwarzania energii elektrycznej i ciepła przy wykorzystaniu źródeł odnawialnych na potrzeby społeczności lokalnej, a także tworzenie warunków regulacyjnych pozwalających na rozwój lokalnych obszarów zrównoważonych energetycznie - klastrów energii, spółdzielni energetycznych itp. Wymienia się w nim następujące działania: promowanie i inicjowanie lokalnych przedsięwzięć (klastry, spółdzielnie energetyczne itp.) z zakresu wytwarzania energii (ze wskazaniem na rozwój OZE) oraz efektywności energetycznej w celu dążenia do samowystarczalności energetycznej gmin i powiatów (autonomiczne obszary energetyczne) [Strategia..., 2017, s. 331].

\section{Wsparcie finansowe dla działań w zakresie modernizacji energetyki}

Zakres działań związanych z modernizacją energetyki jest bardzo szeroki. Obejmuja one nie tylko dywersyfikację źródeł energii i zwiększenie efektywności energetycznej. Konieczna jest zarazem modernizacja i rozbudowa sieci przesyłu oraz dystrybucji energii elektrycznej, gazu, jak również instalacji dla dystrybucji ciepła sieciowego. Inwestycje w konwencjonalnąinfrastrukturę wytwórcza, a jednocześnie wdrożenie energetyki jądrowej 
moga jednak napotkać bariery w sferze finansowania. Podobny problem dotyczy szerszego wykorzystania stabilnych źródeł energii odnawialnej, również tworzenie tzw. rynku mocy dzięki energetyce węglowej raczej nie uzyska wsparcia ze strony międzynarodowych instytucji finansowych. Przed energetyką opartą na węglu pojawiają się także istotne wyzwania wynikające z regulacji w sferze ochrony środowiska [Wojtkowska-Lodej, Graczyk, Szablewski, 2016].

W tym kontekście warto zwrócić uwagę na priorytety finansowania ze środków unijnych. W okresie do 2020 roku są one ściśle związane z głównymi założeniami strategii „Europa 2020”, do których należą:

- rozwój inteligentny: rozwój gospodarki opartej na wiedzy i innowacji;

- $\quad$ rozwój zrównoważony: wspieranie gospodarki efektywniej korzystającej z zasobów, bardziej przyjaznej środowisku i bardziej konkurencyjnej;

- rozwój sprzyjający włączeniu społecznemu: wspieranie gospodarki o wysokim poziomie zatrudnienia, zapewniającej spójność społeczną i terytorialna.

Celem Funduszu Spójności jest zredukowanie dysproporcji gospodarczych i społecznych oraz promowanie zrównoważonego rozwoju. Środki z Funduszu Spójności mogą wspierać realizację projektów związanych z energetyką i transportem, o ile zapewniają ewidentne korzyści dla środowiska w zakresie wydajności energetycznej i wykorzystywania odnawialnych źródeł energii. Obszary tematyczne Europejskiego Funduszu Rozwoju Regionalnego to m.in.: wspieranie transformacji w kierunku gospodarki niskoemisyjnej we wszystkich sektorach, promowanie dostosowania do zmiany klimatu, zapobieganie ryzyku i zarządzanie ryzykiem, ochrona środowiska i promowanie efektywnego gospodarowania zasobami.

Nowym elementem przyszłej polityki regionalnej Unii Europejskiej jest działanie łączące Europe, które akcentuje problem spójności w kontekście międzyregionalnym [Greta, Tomczak-Woźniak, 2013]. Po 2020 roku fundusze unijne nadal będą stanowiły istotne źródło finansowania inwestycji prorozwojowych w Polsce. Zapowiadane jest m.in. tworzenie na poziomie Unii Europejskiej nowych instrumentów ukierunkowanych sektorowo (z odmiennym kluczem dystrybucji w stosunku do polityki spójności) oraz wzrost wydatków na innowacyjność i na działania obejmujące zmiany klimatu.

Istniejace i zapowiadane zasady finansowania inwestycji będą raczej sprzyjać projektom z zakresu energetyki rozproszonej, bazującej na odnawialnych i innowacyjnych źródłach energii. Prawdopodobnie będzie to czynnikiem wzmocnienia tego obszaru działań w Strategii, a zarazem pożytkiem związanym z osiaganiem celów spójności.

\section{Podsumowanie}

Analiza Strategii pozwoliła stwierdzić, że zasadniczym wyznacznikiem podejścia do osiagania spójności jest spójność społeczna. Zamierzenia dotyczące energetyki są niedostosowane do tej opcji rozwoju.

W Strategii zapowiada się preferencje dla wytwarzania energii elektrycznej bazującego na kosztownych technologiach weglowych i ciepła opartego na jednych z najdroższych technologii biomasowych. Zapewnienie powszechnego dostępu do energii pochodzącej 
z różnych źródeł oznacza wybór rozwiązań generujących nadmierne koszty. Będzie to także godzić w osiaganie celów w zakresie spójności: społecznej, ekonomicznej i terytorialnej. Spowoduje duży wzrost kosztów wytwarzania, a w ślad za tym, cen energii dla odbiorców. Ponadto, koszty i ceny energii będą rosły ze względu na rosnące koszty środowiskowe.

W kontekście osiagania spójności za właściwy można uznać kierunek działań określanych jako energetyka rozproszona. Będą im również sprzyjać istniejące i zapowiadane zasady finansowania inwestycji ze źródeł unijnych. Są one istotnym elementem rozwoju zrównoważonego.

\section{Literatura}

Borys T., 1999, Wskaźniki ekorozwoju, Wydawnictwo Ekonomia i Środowisko, Białystok. Europejska strategia na ræecz zrównoważonej, konkurencyjnej i bępiecznej energii, wersja ostatecæna, 2006, KOM (2006) 105, Komisja Europejska, Bruksela.

Gospodarowicz M., 2016, Ocena spójności terytorialnej pod wagledem społecznym i gospodarçym gmin w Polsce, Konferencja IERiGZ̈-PIB, „Konkurencyjność gospodarki w kontekście działań polityki społecznej”, Jachranka, 22-24 czerwca 2016 roku, http:/ / docplayer.pl/40879927-Ocena-spojnosci-terytorialnej-pod-wzgledemspolecznym-i-gospodarczym-gmin-w-polsce.html (data wejścia: 17.05.2017).

Graczyk A., Wielewska I., Piaskowska-Silarska M., 2017, Rozwój odnawialnych źródet energii w Polsce. Problemy bezpieczeństwa energetycznego i lokalnego wykorzystania zasobów, Texter, Warszawa.

Greta M., Tomczak-Woźniak E., 2013, Problem spójności w nowej polityce regionalnej UE na lata 2014-2020, „Optimum. Studia Ekonomiczne”, nr 4(64).

Strategia na rzecz. Odpowiedzialnego Rozwoju do roku 2020 (z perspektywa do 2030 roku), 2017, Ministerstwo Rozwoju. Departament Strategii Rozwoju, Warszawa, https://www.mr.gov.pl/media/36848/SOR_2017_maly_internet_03_2017_aa.pdf (data wejścia: 17.05.2017).

Sustainable Development Goals. Cele Zrównoważonego Rozwoju, 2015, Platforma SDG, UNIC Warszawa, http://www.un.org.pl/cel7 (data wejścia: 17.05.2017).

Wersje skonsolidowane Traktatu o Unii Europejskiej $i$ Traktatu o funkecjonowaniu Unii Europejskiej - Traktat o Unii Europejskiej, Dz. Urz. C 326, 26/10/2012 P. 0001 - 0390.

Wojtkowska-Łodej G., Graczyk A., Szablewski A.T., 2016, Uwarunkowania rozwoju energetykei w zakeresie polityki energetycznej i regulacyjnej, Dom Wydawniczy Elipsa, Warszawa. 